\title{
Entrepreneurial Intentions among Engineering Students: Applying a Theory of Planned Behavior Perspective
}

\author{
Alejandro Valencia-Arias ${ }^{1 *}$, Luz Alexandra Montoya Restrepo² \\ ${ }^{1}$ Departamento de Ciencias Administrativas, Facultad de Ciencias Económicas y Administrativas, Instituto Tecnológico \\ Metropolitano, Calle 54 A \#30-01, Medellín, Colombia \\ 2 Departamento de Ingeniería de la Organización, Facultad de Minas, Universidad Nacional de Colombia, \\ Av. 80 \#65 - 223, Medellín, Colombia \\ * Corresponding author, e-mail: jhoanyvalencia@itm.edu.co
}

Received: 21 June 2018, Accepted: 29 May 2019, Published online: 11 December 2019

\begin{abstract}
This research employs the Theory of Planned Behavior in an attempt to identify the factors that exert an influence on the entrepreneurial intentions of undergraduate students. The authors hope to contribute to understanding the process of entrepreneurial intentions in engineering students in the context of a developing country, taking as an example engineering students in the city of Medellín. Descriptive field and cross-sectional research was conducted using a quantitative methodological design. Data was collected using a self-administered questionnaire. The sample was made up of 636 undergraduate engineering students. Following validation, statistical Somers' D was used to evaluate the associations between the constructs found in the Theory of Planned Behavior. It proved possible to corroborate the influence of attitudes, perceived behavioral control, current behavioral control and entrepreneurial behavior on the intention of engineering students to create a business in the future. The authors propose that current behavioral control is the most influential factor on entrepreneurial intention in engineering students. Consequently, university entrepreneurial education initiatives and efforts to motivate entrepreneurship need to be accompanied by programs that help students identify business opportunities and financial mechanisms that will allow fledgling entrepreneurs to feel confident in their personal capacities (attitudes) and their ability to access financial support to help them create businesses.
\end{abstract}

\section{Keywords}

theory of planned behavior, students' attitudes, higher education, engineering students

\section{Introduction}

In recent decades the study of business creation processes has become an increasingly important research area in the field of business and management (Cefis and Marsili, 2011; Pulgarin and Cardona, 2016). The first stage in this process involves the formation of intentions (Lee et al., 2011). Accordingly, the academic literature has extensively researched the area of entrepreneurial intentions (Liñán et al., 2013; Fayolle and Liñán, 2014), as it provides the best explanation of the processes involved in identifying opportunities and developing entrepreneurship (Sánchez, 2011; Mejía Ordoñez et al. 2017).

Entrepreneurial intentionality may be defined as a state of mind that focuses the attention of individuals on meeting a specific objective and that has some influence on the actions an individual will take to achieve the desired result, in this case, the creation of a company or business
(Prodan and Drnovsek, 2010). In this regard, researchers have proposed several models of entrepreneurial intention that have helped identify the relevant determinant factors (Küttim et al., 2014).

The principal approaches that have served as a guide to the proper understanding of the development of entrepreneurial intentions are: the Implementing Entrepreneurial Ideas Model (Bird, 1988), the Model of Entrepreneurial Intention (Segal et al., 2005), the Entrepreneurial Event Model (Shapero and Sokol, 1982) and the Theory of Planned Behavior, or TPB (Ajzen, 1991). There is sufficient empirical evidence to support the applicability of the last two models (Krueger et al., 2000; Liñán and Fayolle, 2015), as they have identified the basic cognitive elements that precede intention and have been solidly tested and validated in the recent literature (Zhang et al., 2014). 
The versatility and robustness of models that focus on intentions permit a better understanding of the nature of intentional behavior (Moreno-Agudelo and Valencia-Arias, 2017), helping to explain the reasons why many entrepreneurs decide to start a business (Krueger and Carsrud, 1993). Despite being conceptually different, these models have similar explanatory power (Botsaris and Vamvaka, 2012).

Various studies have contributed to the dissemination and application of entrepreneurial intention models, confirming their applicability in different contexts (Liñán and Chen, 2009). On this point, it is important to note that although it has not been possible to articulate a single model of entrepreneurial intention, compatibility has been shown between several of those that exist (Krueger et al., 2000). As a result, the topic is now recognized as a focus of analysis in entrepreneurial intention models.

The Entrepreneurial Event Model (Shapero and Sokol, 1982) and TPB (Ajzen, 1991) are conceptually different, the latter being the approach that has been validated most frequently, and that is best supported by empirical evidence (Fayolle and Liñán, 2014; Zapkau et al., 2015; Torres Velásquez et al., 2016). Although TPB has been positioned as a tool for understanding the process by which new organizations emerge (Liñán and Fayolle, 2015; Echeverri et al., 2018), it has principally been validated in the context of developed countries, and still requires further conceptual and methodological work to explore its applicability in other demographic, social and cultural contexts (Liñán and Fayolle, 2015). For example, in the Latin American context
Hernández-López et al. (2018) conclude that there is a significant association between the perceived convenience of entrepreneurship and its perceived feasibility.

The study of TPB has focused on the different constructs and relations involved in the approach, which in some cases have been examined in isolation. This has allowed variations between these constructs and relations to be tested. The fragmentation of the theory has led to an increase in the number of publications on the subject. However, it has also led to new questions regarding the theory, creating a need for integrative studies to confirm the entire theory rather than mere parts of it (Valencia-Arias et al., 2017). Of particular importance among these studies are those of Souitaris et al., (2007) and Saadin and Daskin (2015), which confirmed the relationship between the various constructs and entrepreneurial intention, suggesting that attitudes, subjective norms and behavioral control are significant predictors of the intention to start a business.

TPB explains comportment by assessing individual behavior (attitudes), social pressure on behavior (subjective norms) and the perception of how easy it is for individuals to adopt that behavior (behavioral control). In addition, a predictor may be identified for each of these factors. Several considerations concerning behavior are described by these predictors, the first of which is beliefs about the consequences of behavior (behavioral beliefs), the second involves beliefs concerning the expectations of others (normative beliefs) and third beliefs about elements that facilitate or hinder behavior (control beliefs) (Maes et al., 2014). Fig. 1 is a schematized presentation of the TPB model.

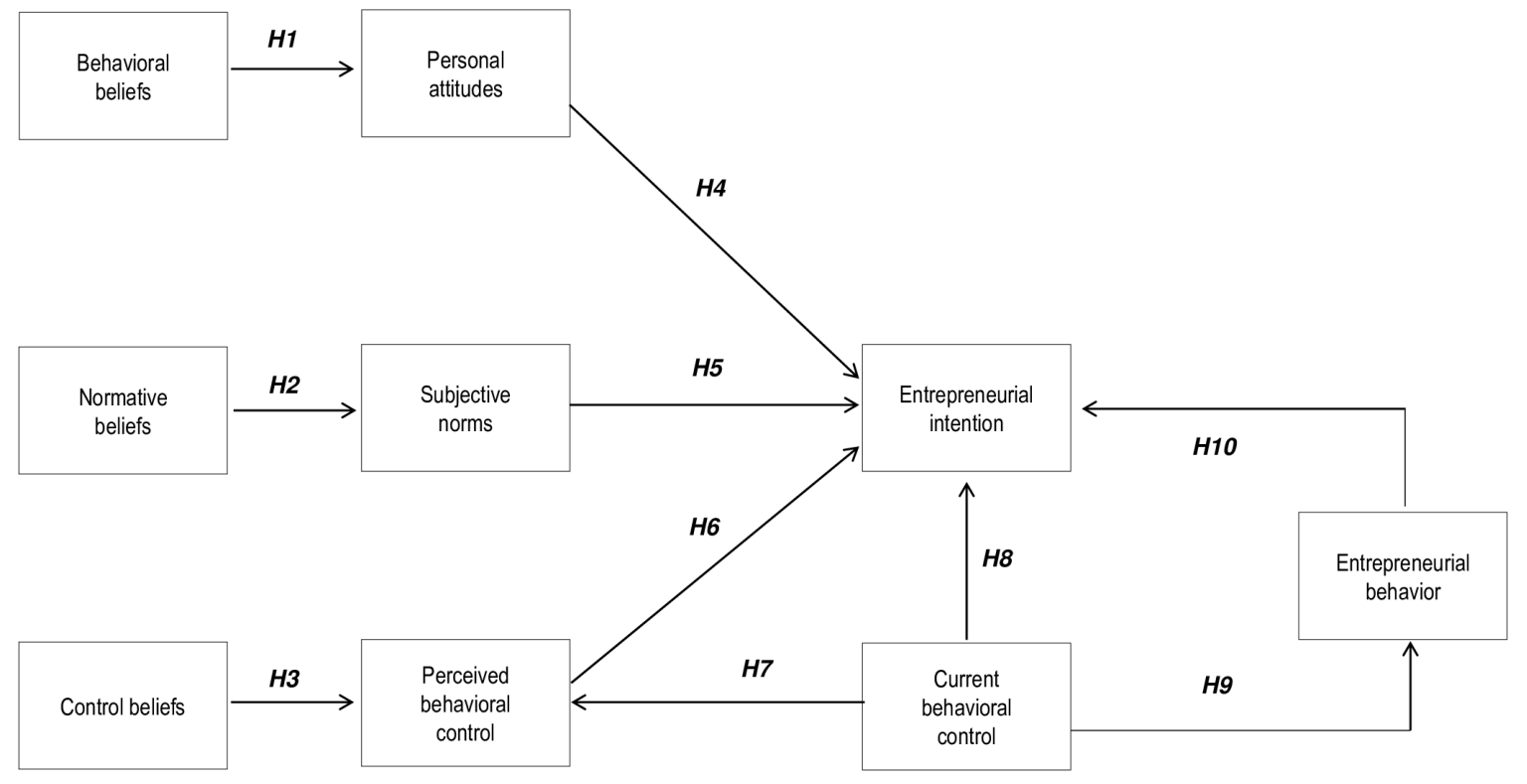

Fig. 1 Theory of planned behavior. Source: Prepared by the author 
Undergraduate students were chosen as the subjects of this research, as they are considered to be representative of the population as a whole, enabling the development of a reliable statistical model of the behavior under examination (Harrison and List, 2004). Furthermore, students comprise a population group that is considered to represent a pool of potential future entrepreneurs (Sánchez, 2013). Furthermore, compared to other population groups the creative and innovative capacity of engineering students is reflected in a greater likelihood that they will perceive and respond to new entrepreneurial opportunities (Naktiyok et al., 2010). This is necessary if the personal, institutional and social factors which exert an influence on the decision by undergraduate students to start a business is to be properly understood (Ferreira et al., 2012; Cadavid et al., 2016).

This article, then, employs the ETB model in order to identify the factors that influence the entrepreneurial intentions of undergraduate students, and to contribute to building an understanding of the process of entrepreneurial intentions in engineering students in a developing country context, specifically in the city of Medellín.

The following sections first provide a description of the methodological design of the data collection. Subsequently, the convergent validity, discriminant validity and the reliability of the instrument are examined, in order to carry out an estimation of the structural model using the proposed hypothesis, and with particular reference to TPB. Finally, the theoretical and practical implications of the findings of this research are discussed.

\section{Methodology}

Descriptive field and cross-sectional research was carried out according to a quantitative methodological design. A self-administered questionnaire was employed to collect data. The questionnaire was developed by carrying out a search of studies published in indexed international journals and written by the most recognized authors on the subject, from which a database containing 168 questions was constructed. Of these, 106 questions were validated using Cronbach's alpha and confidence coefficient or factor analysis. The most widely-used scale (present in 146 of the original questions) was the Likert scale. In total, questions directly associated with nine constructs related to TPB approaches were taken into account, which were then coded for the subsequent development of the questionnaire. In choosing the questions, validations presented in previous studies were taken into account, in order to ensure that construct-variable relationships were established correctly. Likert scale type questions were favored to facilitate the analysis of results, as it is the commonest scale used, and makes a greater diversity of information available for validating the models (Álvarez Rodríguez et al., 1997).

The resulting questionnaire was self-administered in an attempt to keep costs down, and ensure convenience and speed and (Suárez Vázquez et al., 2009). Students from the Medellín campus of the Universidad Nacional de Colombia (with 17 engineering programs) and of the Instituto Tecnológico Metropolitano (with nine programs) were selected, as together they account for the largest number of engineering students in the city. In the semester during which the survey was conducted (02-2015), the two institutions had, respectively, 2,148 and 1,845 active students, who had been studying for more than four semesters.

The sample consisted of 327 students from the Universidad Nacional de Colombia and 319 from the Instituto Tecnológico Metropolitano. The sample size was calculated using simple random sampling with $50 \%$ heterogeneity, a $5 \%$ of margin of error and a confidence level of $95 \%$. However, 11 of the total of 647 samples were removed because their information was incomplete, resulting in a total of 636 validated questionnaires that were available for analysis. A pilot test was conducted prior to the data collection in order to assess the clarity of the questionnaire and ensure its structure could be understood. Subsequently, the final version of the instrument was adjusted and applied to the target population, after which the data were tabulated and statistical analyses carried out.

Initial analysis of the results involved an assessment of the convergent validity of the measurement scales used in a confirmatory factor analysis, examining for factor loadings of observable variables that were greater than 0.5 (Bagozzi and Yi, 1988), with an average exceeding 0.7 (Hair et al., 1999). Subsequently the Bartlett's sphericity test and the KMO test for sampling adequacy were applied. Next, discriminant validity, a standard criterion for evaluating measure scales of latent constructs in the social sciences, was assessed (Martínez-García and MartínezCaro, 2009). The test was implemented by checking that the interval confidence in estimating the correlation between each pair of factors did not contain the value of 1 (Anderson and Gerbing, 1988). In addition, the internal consistency reliability of the instrument was estimated using Cronbach's alpha, a trusted tool in which it is assumed that the items on the Likert scale measure the same construct, and are highly correlated (Welch and Comer, 1988). 
After validation, the associations between the TPB constructs were evaluated using Somers' D statistical. This corresponds to a measure of association between two ordinal variables that take a value between -1 and +1 , where extreme values mean perfect concordance or discordance and values close to 0 indicate no association (Kaplan, 2008; Valencia-Arias et al., 2019). This statistical treatment makes it possible to verify the explanatory power of TPB in assessing entrepreneurial intentions among undergraduate students of engineering in the city of Medellin.

\section{Analysis of results}

Initially, questions formulated to measure a single dimension were restructured into a unique fictitious variable. The process adopted was as follows: scores for each variable were added algebraically using numerical expressions, thereby generating a single variable construct as a result of the sum of scores for all the other expressions that were part of the construct. Subsequently a confirmatory factor analysis was conducted of the items making up the scale, in order to obtain small dimensions and work with them, so that each factor obtained took the variable form.

\subsection{Convergent validity}

The validity of the measurement scales was verified using a confirmatory factor analysis, because with this method it is possible to identify the validity of the underlying structures (factors), dimensions and latent concepts, and as a result the amount of data is reduced. The approach also allows an empirical exploration of the factors to be carried out, bearing in mind that the objective is to select those items that are most correlated with the set of items used to measure the construct (Mora, 2005).

However, during the development of the validation process it was not necessary to eliminate any indicators, as standardized factor loading generated results greater than 0.6, which is considered to be evidence that the model is reliable (Bagozzi and Yi, 1988). Average loads were in fact higher than 0.7 for all constructs (Hair et al., 1999) as shown in Table 1.

To improve correlation between variables, the Bartlett sphericity test and the KMO were used to measure the adequacy of the sample and the level of conditioning of the model was determined so that a factor analysis could be carried out. Since for the proposed model in this research Bartlett values are lower than 0.05 , it may be said that there are significant correlations between the variables.
Table 1 Convergent validity of standardized factor. Source: Prepared by the author

\begin{tabular}{|c|c|c|c|}
\hline Construct & Item & $\begin{array}{l}\text { Standardized } \\
\text { factor loadings }\end{array}$ & $\begin{array}{c}\text { Average of } \\
\text { standardized } \\
\text { factor loadings }\end{array}$ \\
\hline \multirow{3}{*}{$\begin{array}{l}\text { Personal } \\
\text { Attitudes (PA) }\end{array}$} & AP1 & 0.758 & 0.764 \\
\hline & AP2 & 0.740 & \\
\hline & AP3 & 0.793 & \\
\hline \multirow{3}{*}{$\begin{array}{l}\text { Behavioral } \\
\text { Beliefs (BB) }\end{array}$} & $\mathrm{CC} 1$ & 0.775 & 0.703 \\
\hline & $\mathrm{CC} 2$ & 0.773 & \\
\hline & $\mathrm{CC} 3$ & 0.562 & \\
\hline $\begin{array}{l}\text { Current } \\
\text { Behavioral } \\
\text { Control (CBC) }\end{array}$ & CCA1 & DNA & DNA \\
\hline \multirow{3}{*}{$\begin{array}{l}\text { Perceived } \\
\text { Behavioral } \\
\text { Control (PBC) }\end{array}$} & CCP1 & 0.534 & 0.721 \\
\hline & $\mathrm{CCP} 2$ & 0.815 & \\
\hline & $\mathrm{CCP} 3$ & 0.814 & \\
\hline \multirow{3}{*}{$\begin{array}{l}\text { Entrepreneurial } \\
\text { Behavior (EB) }\end{array}$} & CE1 & 0.732 & 0.744 \\
\hline & CE2 & 0.783 & \\
\hline & CE3 & 0.717 & \\
\hline \multirow{3}{*}{$\begin{array}{l}\text { Normative } \\
\text { Beliefs (NB) }\end{array}$} & $\mathrm{CN} 1$ & 0.836 & 0.853 \\
\hline & $\mathrm{CN} 2$ & 0.887 & \\
\hline & $\mathrm{CN} 3$ & 0.835 & \\
\hline \multirow{2}{*}{$\begin{array}{l}\text { Control Beliefs } \\
\text { (CB) }\end{array}$} & $\mathrm{CPC} 1$ & 0.761 & 0.761 \\
\hline & $\mathrm{CPC} 2$ & 0.761 & \\
\hline \multirow{3}{*}{$\begin{array}{l}\text { Entrepreneurial } \\
\text { Intention (EI) }\end{array}$} & IE1 & 0.830 & 0.834 \\
\hline & IE2 & 0.856 & \\
\hline & IE3 & 0.817 & \\
\hline \multirow{3}{*}{$\begin{array}{l}\text { Subjective } \\
\text { Norms (SN) }\end{array}$} & NS1 & 0.870 & 0.849 \\
\hline & NS2 & 0.820 & \\
\hline & NS3 & 0.858 & \\
\hline
\end{tabular}

Furthermore, the KMO value is greater than 0.5, and is therefore acceptable (Lévy-Mangin and Varela, 2006). Table 2 shows that the coefficients generated using SPSS software for each of constructs meet the above criteria, indicating that it is feasible to use the data reduction technique.

\subsection{Discriminant validity}

Discriminant validity is a commonly used criterion for evaluating measurement scales of latent constructs in the social sciences. At this stage it is stated that for measures to be considered valid, those belonging to the same construct should be highly correlated and that correlation should be higher than the measures proposed for a different construct (Martínez-García and Martínez-Caro, 2009). In this research, discriminant validity analysis was carried out by checking that the interval confidence in the estimation of 
Table 2 Convergent validity of the KMO measure and Bartlett's sphericity test. Source: Prepared by the author.

\begin{tabular}{llll}
\hline Factor & KMO value & Bartlett value & Meets the criteria \\
\hline $\begin{array}{l}\text { Personal } \\
\text { Attitudes (PA) }\end{array}$ & 0.646 & 0 & Yes \\
$\begin{array}{l}\text { Behavioral } \\
\text { Beliefs (BB) }\end{array}$ & 0.572 & 0 & Yes \\
$\begin{array}{l}\text { Perceived } \\
\text { Behavioral } \\
\text { Control (PBC) }\end{array}$ & 0.565 & 0 & Yes \\
$\begin{array}{l}\text { Entrepreneurial } \\
\text { Behavior (EB) }\end{array}$ & 0.629 & 0 & \\
$\begin{array}{l}\text { Normative Beliefs } \\
\text { (NB) }\end{array}$ & 0.698 & 0 & Yes \\
$\begin{array}{l}\text { Control Beliefs } \\
\text { (CB) }\end{array}$ & 0.500 & 0 & Yes \\
$\begin{array}{l}\text { Entrepreneurial } \\
\text { Intention (EI) }\end{array}$ & 0.699 & 0 & Yes \\
$\begin{array}{l}\text { Subjective Norms } \\
\text { (SN) }\end{array}$ & 0.705 & 0 & Yes \\
\hline
\end{tabular}

the correlation between each pair of factors did not contain a value of 1 (Anderson and Gerbing, 1988). Table 3 shows that all cases met that criterion and it is thus found that the instrument used is indeed effective in carrying out the intended measurement.

Furthermore, the internal consistency reliability of the instrument was estimated using Cronbach's alpha. George and Mallery (2011) suggest the following guidelines to evaluate the Cronbach's alpha coefficients: alpha coefficient $>0.9$ is excellent, alpha coefficient $>0.8$ is good, alpha coefficient $>0.7$ is acceptable, alpha coefficient $>0.6$ is questionable, alpha coefficient $>0.5$ is poor and alpha coefficient $<0.5$ is unacceptable. Table 4 shows the measuring instrument and corroborates an adequate internal consistency reliability for the measurement scale, as all Cronbachs' alpha are between the recommended value ranges.
Table 4 Reliability rate - Cronbach's Alpha. Source: Prepared by the author

\begin{tabular}{lc}
\hline Factor & Cronbach's Alpha \\
\hline Personal attitudes (PA) & 0.812 \\
Behavioral beliefs (BB) & 0.744 \\
Current behavioral control (CBC) & $\ldots$ \\
Perceived behavioral control (PBC) & 0.777 \\
Entrepreneurial behavior (EB) & 0.788 \\
Normative beliefs (NB) & 0.900 \\
Control beliefs (CB) & 0.744 \\
Entrepreneurial intention (EI) & 0.884 \\
Subjective norms (SN) & 0.896 \\
\hline
\end{tabular}

The convergent validity and discriminant validity within the instrument were confirmed and, along with acceptable reliability, illustrate the initial existence of a sustainable factor model for the analysis. This model was based on research into factors affecting the intention of undergraduate engineering students in Medellin to create a business.

\subsection{Contrast hypothesis}

The proposed structural model was estimated by collecting the suggested hypotheses and their degree of association which were measured using Somer's D. This corresponds to a measure of association between two ordinal variables that takes a value between -1 and +1 , where values close to 1 in absolute value indicate a strong relationship between the two variables, and values close to zero indicate little or no relationship between the two variables (Abascal and Grande, 2005).

The statistical analysis was processed using SPSS software and placed in a table of crossed factors, in order to observe the degree of association between the variables that were part of the hypotheses and to check the degree of association for hypothetical relationships, and at the same time confirming that there was not a high level of

Table 3 Discriminant validity of the measurement model. Source: Prepared by the author

\begin{tabular}{|c|c|c|c|c|c|c|c|c|c|}
\hline & PA & $\mathrm{BB}$ & $\mathrm{CBC}$ & $\mathrm{PBC}$ & EB & NB & $\mathrm{CB}$ & EI & $\mathrm{SN}$ \\
\hline PA & $\ldots$ & & & & & & & & \\
\hline $\mathrm{BB}$ & {$[0.44 ; 0.57]$} & $\ldots$ & & & & & & & \\
\hline $\mathrm{CBC}$ & {$[0.48 ; 0.60]$} & {$[0.36 ; 0.49]$} & $\ldots$ & & & & & & \\
\hline $\mathrm{PBC}$ & {$[0.36 ; 0.50]$} & {$[0.34 ; 0.48]$} & {$[0.31 ; 0.43]$} & $\ldots$ & & & & & \\
\hline $\mathrm{EB}$ & {$[0.37 ; 0.51]$} & {$[0.35 ; 0.49]$} & {$[0.35 ; 0.48]$} & {$[0.48 ; 0.60]$} & $\ldots$ & & & & \\
\hline NB & {$[0.37 ; 0.49]$} & {$[0.33 ; 0.48]$} & {$[0.23 ; 0.37]$} & {$[0.39 ; 0.52]$} & {$[0.36 ; 0.49]$} & $\ldots$ & & & \\
\hline $\mathrm{CB}$ & {$[0.13 ; 0.29]$} & {$[0.19 ; 0.35]$} & {$[0.09 ; 0.24]$} & {$[0.17 ; 0.33]$} & {$[0.15 ; 0.31]$} & {$[0.12 ; 0.28]$} & $\ldots$ & & \\
\hline EI & {$[0.52 ; 0.64]$} & {$[0.32 ; 0.46]$} & {$[0.49 ; 0.61]$} & {$[0.48 ; 0.60]$} & {$[0.46 ; 0.58]$} & {$[0.45 ; 0.57]$} & {$[0.10 ; 0.26]$} & $\ldots$ & \\
\hline SN & {$[0.06 ; 0.21]$} & {$[0.19 ; 0.33]$} & {$[0.07 ; 0.23]$} & {$[0.050 ; 0.21]$} & {$[0.04 ; 0.20]$} & {$[0.15 ; 0.30]$} & {$[0.07 ; 0.22]$} & {$[0.02 ; 0.17]$} & $\ldots$ \\
\hline
\end{tabular}


Table 5 Unidirectional Somers' D for the proposed model. Source: Prepared by the author.

\begin{tabular}{|c|c|c|c|c|c|c|c|c|c|}
\hline & PA & BB & $\mathrm{CBC}$ & PBC & EB & NB & $\mathrm{CB}$ & EI & SN \\
\hline PA & 1 & & & & & & & & \\
\hline BB & 0.460 & 1 & & & & & & & \\
\hline $\mathrm{CBC}$ & 0.562 & 0.436 & 1 & & & & & & \\
\hline PBC & 0.411 & 0.412 & 0.239 & 1 & & & & & \\
\hline EB & 0.410 & 0.385 & 0.431 & 0.492 & 1 & & & & \\
\hline NB & 0.414 & 0.392 & 0.329 & 0.375 & 0.395 & 1 & & & \\
\hline $\mathrm{CB}$ & 0.187 & 0.252 & 0.168 & 0.232 & 0.217 & 0.157 & 1 & & \\
\hline EI & 0.559 & 0.367 & 0.591 & 0.488 & 0.480 & 0.457 & 0.155 & 1 & \\
\hline SN & 0.120 & 0.239 & 0.155 & 0.115 & 0.106 & 0.204 & 0.139 & 0.365 & 1 \\
\hline
\end{tabular}

association between other constructs. Table 5 shows the Somers' D association values obtained for the proposed constructs in TPB.

Finally, Fig. 2 shows the compiled results of the proposed association hypothesis for TPB as applied to the evaluation of entrepreneurial intention in undergraduate engineering students in the city of Medellin (arrows indicate the validated hypotheses in the research).

\section{Discussion}

The analysis of the results confirms that it is important for engineering students to feel that they have access to the resources and opportunities they require to create a business, as it is observed that the strongest influence, with a Somers' $\mathrm{D}$ of 0.591 , occurs between the current behavioral control and entrepreneurial intention. Ozkan and Kanat (2011) and
Moriano et al. (2011) found that individuals usually prefer to adopt behaviors that help them feel they have more control over their situations. That is to say, they will prefer those behaviors that make them feel they have a degree of knowledge of the preceding series of events.

Despite the importance of controlling current behavior, research shows that its influence over perceived behavioral control is weak (Somers' D $=0.168$ ). This does not negatively impact entrepreneurial intention, where the relationship is very direct, which contrasts with the situation for perceived behavioral control, where it acts as a mediating variable. However, control of current behavior has a high degree of influence on entrepreneurial behavior (Somers' D = 0.431). This may be because it involves the administration of resources for the use of recognized opportunities (van Dam et al., 2010). This is because entre-

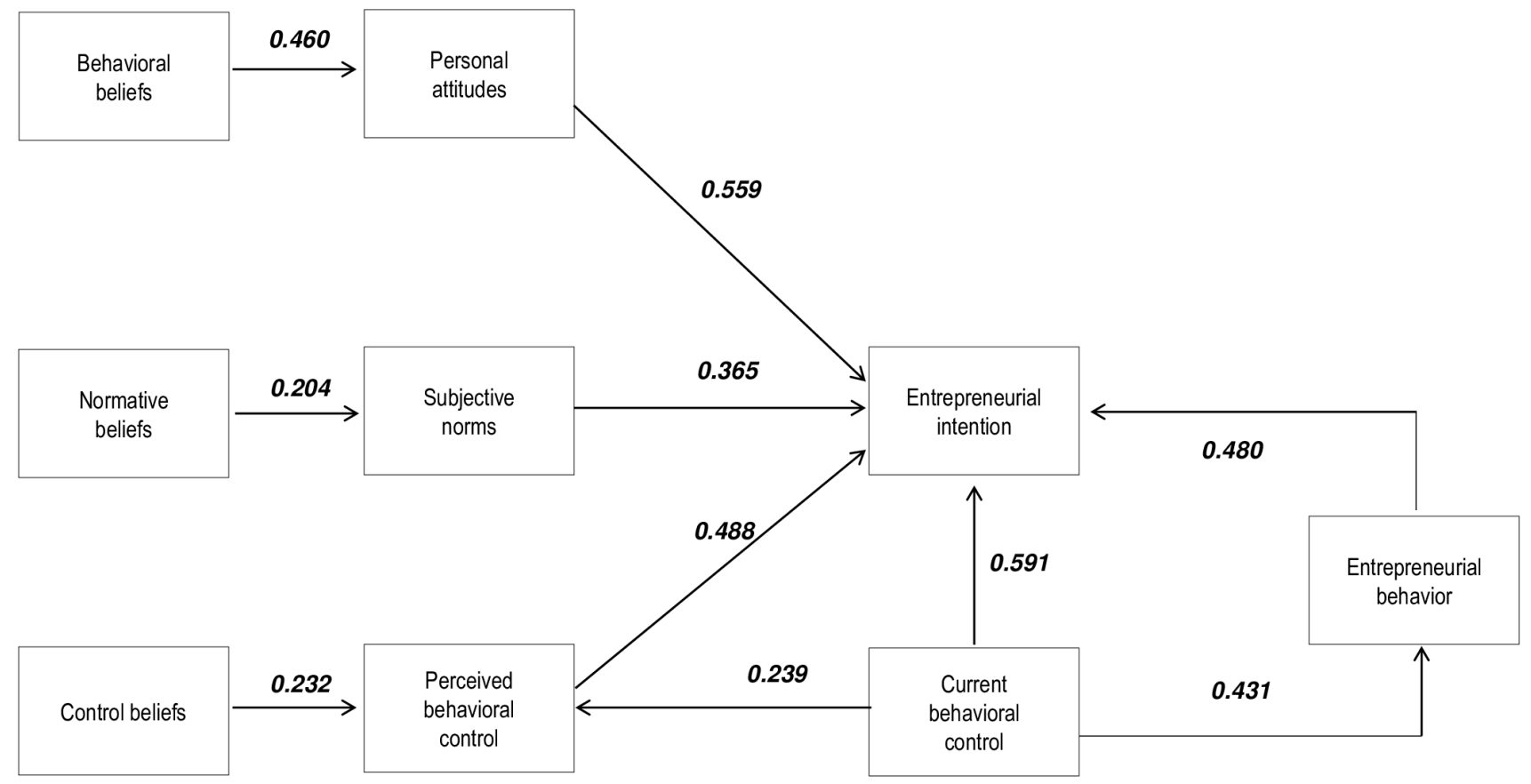

Fig. 2 Relationship results of proposed model. Source: Prepared by the author 
preneurial behavior involves a post-process opportunity identification stage, and is related to the business education of each individual. This component is common to the population surveyed.

On the other hand, entrepreneurial behavior displays a strong relationship with entrepreneurial intention (Somers' $\mathrm{D}=0.480$ ). This may be because respondents are being trained as future professionals, which, according Schreier and Prügl (2011), is reflected in an increased likelihood of support for business creation, reflected in goals and visions more ambitious than those entertained by individuals who have not received training or support. Conversely, the role played by the economic and business environment as one of the influential entrepreneurial intention factors is also highlighted, as these social, economic and cultural variations generate differences in the entrepreneurial behavior of individuals (Bosma et al., 2008).

Regarding the influence of personal attitudes on entrepreneurial intention which had a Somers' D of 0.559, it may be affirmed that individuals display a high level of belief that their performance will lead to successful business creation, a finding that is consistent with those of Marques et al. (2012), who affirm that there is a positive relationship between attitude and intention, with a high level of significance. Among the factors that may explain this attitude are the personal satisfaction that leads to an entrepreneurial lifestyle, as such a lifestyle is associated with feelings of self-improvement, the achievement of expectations and personal success (Marcketti et al., 2006). These results are positive in that a favorable personal attitude helps individuals focus clearly on the purpose of creating a business, because they find the goal attractive (Bird, 1988; Krueger and Carsrud, 1993).

In addition, it is observed that behavioral beliefs have a strong influence on personal attitudes, as indicated by a Somers' D of 0.460 . In the context of entrepreneurship, behavioral beliefs may be defined as expectations about advantages and disadvantages that accrue when an individual starts a business (Marcati et al., 2008). Among the principal advantages that permit existing strong relations between behavioral beliefs and entrepreneurial attitudes to be expressed are financial independence, greater financial reward, risk taking and the desire to achieve personal and professional goals (Henderson, 2002; Quiroga-Juárez and Villalobos-Escobedo, 2015).

Another strong relationship found in the model corresponds to the influence of perceived behavioral control on entrepreneurial intention (Somers' $\mathrm{D}=0.488$ ). This finding is corroborated in other studies (Marques, 2012; Karimi et al., 2013; Yurtkoru et al., 2014). Perceived behavioral control may be interpreted as the possibility that students perceive that that they are able to perform a certain action (Sondari, 2014), in this case, creating a company. The significant relationship between these two constructs shows that the engineering students surveyed consider that decisions relating to entrepreneurship are their own, and that personal factors such as their life lessons and experiences predispose individuals to entrepreneurial intention, as argued by Moriano et al. (2011) in their research on the psychosocial profile of the entrepreneur.

On the other hand, it has been observed that in this study the influence of subjective norms on entrepreneurial intention is weak (Somers' $\mathrm{D}=0.365$ ). In the context of Latin American students, three groups of people have been identified as the most influential in motivating young people to create a company: outsiders, wider family members, and parents (Bolaños, 2006).

The results of the current research, however, suggest that undergraduate engineering students do not prioritize the points of view of significant figures in their lives when they consider creating companies. In this regard, several studies have been carried out over the last 20 years with the intention of verifying the explanatory capacity and the variants of TPB. As a result it has been possible to validate the relationship between attitude and perceived control regarding entrepreneurial intentions. However, the findings on subjective norms have been contradictory (Engle et al., 2010). This is also true of this current research, in which it is observed that the points of view of respondents' significant friends, outsiders, wider family members and parents have an insignificant effect on the students' intentions to start a business. These findings are consistent with those of Marques et al. (2012), who found that subjective norms make little contribution to entrepreneurial intention.

In addition, the influence of normative beliefs on subjective norms is weak (Somers' $\mathrm{D}=0.204$ ). This finding is consistent with the proposed results concerning the influence of subjective norms on entrepreneurial intention, as normative beliefs are related to the people who do or do not approve of certain behaviors, though in the case of the engineering students surveyed no strong influence of close associates on the decision to create a business was reported.

Additionally, the influence of control beliefs on perceived behavior is low (Somers' $\mathrm{D}=0.232$ ), showing that perceptions of internal factors (such as the skills of the individual) and external aspects (such as opportunities and constraints 
inherent to the context) are not factors that directly facilitate or inhibit the development of entrepreneurial intention. On this subject, several authors suggest measures to improve levels of control over the beliefs of individuals. These include academic training focused on business creation, and specific knowledge of the field in which the entrepreneurial idea is developed (Moriano et al., 2011; Villafuerte-Godínez et al., 2015). Another measure is to provide improved access to funding mechanisms to assist in the creation of companies, so that entrepreneurs are not forced to rely only on their own resources to establish new enterprises (Van Praag and Versloot, 2007). Furthermore, Bolaños (2006) suggests that one of the key factors in the provision of support to entrepreneurship involves the generation of a real motivation for identifying opportunities to create a business.

\section{Conclusions}

It has been observed that TPB is a useful and coherent model for the study of the entrepreneurial intentions of undergraduate students, its explanatory power being tested for engineering students from the city of Medellin. In this case, it was possible to corroborate the influence of attitudes, perceived behavioral control, current behavioral control and entrepreneurial behavior on the intention of future engineers to create a business.

It seems reasonable to suggest that the strategies implemented by programs and university entrepreneurship centers should focus on strengthening the personal attitudes of individuals toward business creation. In addition, students should be trained in strategies of accessing resources to enable entrepreneurship. In this way, undergraduate students could be encouraged to perceive that sufficient opportunities exist to move from an entrepreneurial intention to concrete actions designed to create a company. The findings are similar in relation to perceived behavior control.

\section{References}

Abascal, E., Grande, E. I. (2005) "Análisis de encuestas" (Analysis of surveys), Esic Editorial, Madrid, Spain. (in Spanish)

Álvarez Rodríguez, B., Cuesta Izquierdo, M., Díaz Ramila, R., Jiménez García, J. M., Paz Caballero, M. D. (1997) "Análisis de las propiedades psicométricas de una escala de actitud: comparación de las técnicas Likert Y Thurstone" (Analysis of the psychometric properties of an attitude scale: comparison of Likert and Thurstone techniques), REMA, 2(2), pp. 23-33. (in Spanish)

Ajzen, I. (1991) "The theory of planned behavior", Organizational Behavior and Human Decision Processes, 50(2), pp. 179-211. https://doi.org/10.1016/0749-5978(91)90020-T
Our findings include the proposal that current behavioral control is the most influential factor on the entrepreneurial intention of engineering students. For this reason it is important that university initiatives to provide entrepreneurial education and encouragement for entrepreneurship are accompanied by capacity building programs aimed at identifying business opportunities, and economic mechanisms that help entrepreneurs feel that they do not have to rely only on their personal capacity (attitude) but also that financial support may be available to help them create a business.

Future research could usefully highlight the issue of subjective norms, since the current research was not able to confirm the influence of social groups (family and friends) on entrepreneurial intentions. It is therefore, important to explore the social referents or "role models" that undergraduate students take into account when making the decision to create a business.

On the other hand, in terms of methodology, it is suggested that longitudinal methodologies will be important in characterizing the transition between intention and action when it comes to creating a business. This would allow the events and factors that make this step possible to be identified. Furthermore, incorporating qualitative methodological strategies (interviews and focus groups) would make it possible to delve into questions such as the role of subjective norms, in order to propose new mediating variables that might explain entrepreneurial intention in developing countries.

It is recommended that future comparative research should be carried out, comparing students drawn from different semesters and academic programs in a single university, in order to identify the effects of a specific training curriculum and the influence of the time spent by students on decisions to create a business. Moreover, it would be worth investigating other predictors that the academic literature has suggested are significant to the creation of a business, including perceived self-efficacy and risk tolerance.

Anderson, J. C., Gerbing, D. W. (1988) "Structural equation modeling in practice: A review and recommended two-step approach", Psychological Bulletin, 103(3), pp. 411-423. https://doi.org/10.1037/0033-2909.103.3.411

Bagozzi, R. P., Yi, Y. (1988) "On the evaluation of structural equation models", Journal of the Academy of Marketing Science, 16(1), pp. 74-94.

https://doi.org/10.1007/BF02723327

Bird, B. (1988) "Implementing Entrepreneurial Ideas: The Case for Intention", Academy of Management Review, 13(3), pp. 442-453. https://doi.org/10.2307/258091 
Bolaños, R. (2006) "Impacto del modelo a imitar en la intención de crear una empresa" (Impact of the model to be imitated in the intention to create a company), Estudios de Economía Aplicada, 24(2), pp. 491-508. (in Spanish)

Bosma, N., Jones, K., Autio, E., Levie, J. (2008) "Global Entrepreneurship Monitor 2007 Executive Report", Global Entrepreneurship Research Consortium (GERA), London, UK.

Botsaris, C. A., Vamvaka, V. (2012) "Models of the determinants of entrepreneurial behaviour: a literature review", Regional Science Inquiry, 4(3), pp. 155-172.

Cadavid, L., Díez-Echavarría, L., Valencia, A. (2016) "Spin-off activities at higher educational institutions: Performance implications from a modeling perspective", Journal of Developmental Entrepreneurship, 22(2), Article number: 1750013. https://doi.org/10.1142/S1084946717500133

Cefis, E., Marsili, O. (2011) "Born to flip. Exit decisions of entrepreneurial firms in high-tech and low-tech industries", Journal of Evolutionary Economics, 21(3), pp. 473-498. https://doi.org/10.1007/s00191-010-0210-4

Echeverri, L., Valencia, A., Benjumea, M., Toro, A. (2018) "Factores que inciden en la intención emprendedora del estudiantado universitario: Un análisis cualitativo" (Factors That Affect the Entrepreneurial Intention in University Students: A Qualitative Analysis), Revista Electrónica Educare, 22(2), pp. 1-19. (in Spanish) https://doi.org/10.15359/ree.22-2.10

Engle, R. L., Dimitriadi, N., Gavidia, J. V., Schlaegel, C., Delanoe, S., Alvarado, I., He, X., Buame, S., Wolff, B. (2010) "Entrepreneurial intent: A twelve-country evaluation of Ajzen's model of planned behavior", International Journal of Entrepreneurial Behavior \& Research, 16(1), pp. 35-57. https://doi.org/10.1108/13552551011020063

Fayolle, A., Liñán, F. (2014) "The future of research on entrepreneurial intentions", Journal of Business Research, 67(5), pp. 663-666. https://doi.org/10.1016/j.jbusres.2013.11.024

Ferreira, J. J., Raposo, M. L., Gouveia Rodrigues, R., Dinis, A., do Paço, A. (2012) "A model of entrepreneurial intention: An application of the psychological and behavioral approaches", Journal of Small Business and Enterprise Development, 19(3), pp. 424-440. https://doi.org/10.1108/14626001211250144

George, D., Mallery, P. (2011) "SPSS for windows step by step: A simple study guide and reference, 17.0 update, 10/e", Pearson Education India, Bengaluru, India.

Hair, J. F., Jr., Anderson, R. E., Tatham, R. L., Black, W C. (1999) "Análisis multivariante" (Multivariate analysis), Prentice Hall Iberia, Madrid, Spain. (in Spanish)

Harrison, G. W., List, J. A. (2004) "Field Experiments", Journal of Economic Literature, 42(4), pp. 1009-1055. https://doi.org/10.1257/0022051043004577

Henderson, J. (2002) "Building the rural economy with high-growth entrepreneurs", Economic Review, 87(3), pp. 45-70.

Hernández-López, D. M., Moncada-Toro, J. F., Henao-Colorado, L. C. (2018) "Intención emprendedora de los empleados del sector privado de la ciudad de Medellín y su Área Metropolitana" (Entrepreneurial intention of the private sector employees of the city of Medellín and its Metropolitan Area), Revista CEA, 4(8), 13-33. (in Spanish) https://doi.org/10.22430/24223182.1045
Kaplan, D. (2008) "Structural equation modeling: Foundations and extensions", Sage Publications, Thousand Oaks, CA, USA.

Karimi, S., Biemans, H. J. A., Lans, T., Chizari, M., Mulder, M., Mahdei, K. N. (2013) "Understanding role models and gender influences on entrepreneurial intentions among college students", ProcediaSocial and Behavioral Sciences, 93, pp. 204-214. https://doi.org/10.1016/j.sbspro.2013.09.179

Krueger, N. F., Carsrud, A. L. (1993) "Entrepreneurial intentions: Applying the theory of planned behaviour", Entrepreneurship \& Regional Development, 5(4), pp. 315-330. https://doi.org/10.1080/08985629300000020

Krueger, N. F., Reilly, M. D., Carsrud, A. L. (2000) "Competing models of entrepreneurial intentions", Journal of Business Venturing, 15(5-6), pp. 411-432. https://doi.org/10.1016/S0883-9026(98)00033-0

Küttim, M., Kallaste, M., Venesaar, U., Kiis, A. (2014) "Entrepreneurship Education at University Level and Students' Entrepreneurial Intentions", Procedia-Social and Behavioral Sciences, 110, pp. 658-668.

https://doi.org/10.1016/j.sbspro.2013.12.910

Lee, L., Wong, P. K., Der Foo, M., Leung, A. (2011) "Entrepreneurial intentions: The influence of organizational and individual factors", Journal of Business Venturing, 26(1), pp. 124-136. https://doi.org/10.1016/j.jbusvent.2009.04.003

Lévy-Mangin, J. P., Varela Mallou, J. (2006) "Modelización con estructuras de covarianzas en ciencias sociales. Temas esenciales, avanzados y aportaciones especiales" (Modeling with covariance structures in social sciences. Essential, advanced topics and special contributions), Netbiblo, A Coruña, Spain, pp. 11-30. (in Spanish)

Liñán, F., Fayolle, A. (2015) "A systematic literature review on entrepreneurial intentions: citation, thematic analyses, and research agenda", International Entrepreneurship and Management Journal, 11(4), pp. 907-933. https://doi.org/10.1007/s11365-015-0356-5

Liñán, F., Nabi, G., Krueger, N. (2013) "British and Spanish entrepreneurial intentions: A comparative study", Revista de economía Mundial, 33, pp. 73-107.

Liñán, F., Chen, Y. W. (2009) "Development and Cross-Cultural Application of a Specific Instrument to Measure Entrepreneurial Intentions", Entrepreneurship Theory and Practice, 33(3), pp. 593-617. https://doi.org/10.1111/j.1540-6520.2009.00318.x

Maes, J., Leroy, H., Sels, L. (2014) "Gender differences in entrepreneurial intentions: A TPB multi-group analysis at factor and indicator level", European Management Journal, 32(5), pp. 784-794. https://doi.org/10.1016/j.emj.2014.01.001

Marcati, A., Guido, G., Peluso, A. M. (2008) "The role of SME entrepreneurs' innovativeness and personality in the adoption of innovations", Research Policy, 37(9), pp. 1579-1590. https://doi.org/10.1016/j.respol.2008.06.004

Marcketti, S. B., Niehm, L. S., Fuloria, R. (2006) "An Exploratory Study of Lifestyle Entrepreneurship and Its Relationship to Life Quality", Family \& Consumer Sciences Research Journal, 34(3), pp. 241-259. https://doi.org/10.1177/1077727X05283632 
Marques, C. S., Ferreira, J. J., Gomes, D. N., Gouveia Rodrigues, R. (2012) "Entrepreneurship education: How psychological, demographic and behavioural factors predict the entrepreneurial intention", Education + Training, 54(8/9), pp. 657-672. https://doi.org/10.1108/00400911211274819

Martínez-García, J. A., Martínez-Caro, L. (2009) "La validez discriminante como criterio de evaluación de escalas: ¿teoría o estadística?" (Discriminant validity as a criterion for evaluating scales: theory or statistics?), Universitas Psychological, 8(1), pp. 27-36. (in Spanish)

Mejía Ordoñez, J. P., Arias Marín, C. M., Echeverri Sánchez, L. C. (2017). "El papel de la educación en creación de empresas en el contexto universitario a partir de los estudios registrados en Scopus" (The role of education in business creation in the university context based on studies registered at Scopus), Revista CEA, 3(5), pp. 69-87. (in Spanish) https://doi.org/10.22430/24223182.651

Mora, H. (2005) "Complementación de métodos en investigación social: Una reflexión en torno a las implicancias teóricas y las prácticas metodológicas" (Complementation of methods in social research: A reflection on the theoretical implications and methodological practices), Antropología y Sociedad, Revista Anthropos, 207, pp. 73-96. (in Spanish).

Moreno-Agudelo, J. A., Valencia-Arias, J. A. (2017) "Factores implicados en la adopción de software libre en las Pyme de Medellín" (Factors involved in the adoption of free software in the SMEs of Medellín), Revista CEA, 3(6), 55-75. (in Spanish) https://doi.org/10.22430/24223182.673

Moriano, J. A., Trejo, E., Palací, F. J. (2001) "El perfil psicosocial del emprendedor: un estudio desde la perspectiva de los valores" (The psycho-social profile of the entrepreneur: A study from the point of view of values), Revista de Psicología Social, 16(2), pp. 229-242. (in Spanish) https://doi.org/10.1174/021347401317351152

Naktiyok, A., Karabey, C. N., Gulluce, A. C. (2010) "Entrepreneurial self-efficacy and entrepreneurial intention: the Turkish case", International Entrepreneurship and Management Journal, 6(4), pp. 419-435.

https://doi.org/10.1007/s11365-009-0123-6

Ozkan, S., Kanat, I. E. (2011) "e-Government adoption model based on theory of planned behavior: Empirical validation", Government Information Quarterly, 28(4), pp. 503-513. https://doi.org/10.1016/j.giq.2010.10.007

Prodan, I., Drnovsek, M. (2010) "Conceptualizing academic-entrepreneurial intentions: An empirical test", Technovation, 30(5-6), pp. 332-347. https://doi.org/10.1016/j.technovation.2010.02.002

Pulgarin, S., Cardona, D. (2016) "Hacia un modelo explicativo del proceso innovador para centros de emprendimiento: una aproximación desde las exaptaciones y la diversidad" (Towards an explanatory model of the innovative process for entrepreneurship centers: an approach based on exaptation and diversity), In: Montoya, I., Montoya, A., Valencia, A., (eds.) Metáforas biológicas aplicadas a las organizaciones (II), Bogotá, Spain, pp. 11-48. (in Spanish)
Quiroga-Juárez, C. A., Villalobos-Escobedo, A. (2015) "Análisis del comportamiento bursátil de las principales bolsas financieras en el mundo usando el análisis multivariado (análisis de componentes principales PCA) para el periodo de 2011 a 2014" (Analysis of the stock market behaviour of the main financial exchanges in the world using multivariate analysis (Principal Components Analysis, PCA) for the period from 2011 to 2014), Revista CEA, 1(2), pp. 25-36. (in Spanish) https://doi.org/10.22430/24223182.122

Saadin, M. N., Daskin, M. (2015) "Perceived desirability, feasibility, and social norms as antecedents on hospitality students' entrepreneurial intention in Malaysia: does gender make a difference?", International Journal of Entrepreneurship and Small Business, 25(4), pp. 456-474

https://doi.org/10.1504/IJESB.2015.070218

Sánchez, J. C. (2011) "University training for entrepreneurial competencies: Its impact on intention of venture creation", International Entrepreneurship and Management Journal, 7(2), pp. 239-254. https://doi.org/10.1007/s11365-010-0156-x

Sánchez, J. C. (2013) "The impact of an entrepreneurship education program on entrepreneurial competencies and intention", Journal of Small Business Management, 51(3), pp. 447-465. https://doi.org/10.1111/jsbm.12025

Segal, G., Borgia, D., Schoenfeld, J. (2005) "The motivation to become an entrepreneur", International Journal of Entrepreneurial Behavior \& Research, 11(1), pp. 42-57. https://doi.org/10.1108/13552550510580834

Shapero, A., Sokol, L. (1982) "The social dimensions of entrepreneurship", In: Kent, C. A., Sexton, D. L., Vesper, K. H. (eds.) Encyclopedia of entrepreneurship, Prentice-Hall, Englewood Cliffs, NJ, USA, pp. 72-90.

Sondari, M. C. (2014) "Is Entrepreneurship Education Really Needed? Examining the Antecedent of Entrepreneurial Career Intention", Procedia-Social and Behavioral Sciences, 115, pp. 44-53. https://doi.org/10.1016/j.sbspro.2014.02.414

Souitaris, V., Zerbinati, S., Al-Laham, A. (2007) "Do entrepreneurship programmes raise entrepreneurial intention of science and engineering students? The effect of learning, inspiration and resources", Journal of Business Venturing, 22(4), pp. 566-591 https://doi.org/10.1016/j.jbusvent.2006.05.002

Suárez Vázquez, A., García Rodríguez, N., Begona Álvarez Álvarez, M. (2009) "La interactividad en cuestionarios autoadministrados. Influencia en la experiencia del encuestado" (Interactivity in self-administered questionnaires. Influence on the respondent's experience), Cuadernos de Economía y Dirección de la Empresa, 12(41), pp. 69-92. (in Spanish) https://doi.org/10.1016/S1138-5758(09)70048-9

Torres Velásquez, J. A., Arias, A. V., Hernández, J. B., Díez-Echavarría, L. F., Urrego Marín, M. L., Maussa Pérez, F. O. (2016) "Characterization of entrepreneurial intention in university students as from Systemic Entrepreneurship Intention Model: A case study", Revista Cuadernos de Gestión, 18(2), pp. 95-114. https://doi.org/10.5295/cdg.160670jt 
Valencia-Arias, A., Gutiérrez Flórez, L., Montoya Restrepo, L. A., Umba López, A. M., Montoya Restrepo, I. (2017) "Consideraciones acerca del emprendimiento estratégico como síntesis funcional de la identificación de oportunidades y la creación de ventajas competitivas" (Considerations of strategic entrepreneurship as a functional synthesis of identifying opportunities and creating competitive advantages), Revista Virtual Universidad Católica del Norte, 52(1), pp. 143-159. (in Spanish)

https://doi.org/10.35575/rvucn.n52a1

Valencia-Arias, A., Chalela-Naffah, S., Bermúdez-Hernández, J. (2019) "A proposed model of e-learning tools acceptance among university students in developing countries", Education and Information Technologies, 24(2), pp. 1057-1071.

https://doi.org/10.1007/s10639-018-9815-2

van Dam, K., Schipper, M., Runhaar, P. 2010) "Developing a competency-based framework for teachers' entrepreneurial behavior", Teaching and Teacher Education, 26(4), pp. 965-971. https://doi.org/10.1016/j.tate.2009.10.038

Van Praag, C. M., Versloot, P. H. (2007) "What is the value of entrepreneurship? A review of recent research", Small Business Economics, 29(4), pp. 351-382.

https://doi.org/10.1007/s11187-007-9074-x
Villafuerte-Godínez, R. Á., Leiva, J. C. (2015) "Cómo surge y se vincula el conocimiento relacionado con el desempeño en las Pymes: un análisis cualitativo" (How knowledge related to SME performance emerges and is linked: a qualitative analysis), Revista CEA, 1(2), 37-48. (in Spanish) https://doi.org/10.22430/24223182.123

Welch, S., Comer, J. (1988) "Quantitative methods for public administration: Techniques and applications", Houghton Mifflin Harcourt, Boston, MA, USA.

Yurtkoru, E. S., Kuşcu, Z. K., Doğanay, A. (2014) "Exploring the Antecedents of Entrepreneurial Intention on Turkish University Students", Procedia-Social and Behavioral Sciences, 150, pp. $841-850$. https://doi.org/10.1016/j.sbspro.2014.09.093

Zapkau, F. B., Schwens, C., Steinmetz, H., Kabst, R. (2015) "Disentangling the effect of prior entrepreneurial exposure on entrepreneurial intention", Journal of Business Research, 68(3), pp. 639-653.

https://doi.org/10.1016/j.jbusres.2014.08.007

Zhang, Y., Duysters, G., Cloodt, M. (2014) "The role of entrepreneurship education as a predictor of university students' entrepreneurial intention", International Entrepreneurship and Management Journal, 10(3), pp. 623-641.

https://doi.org/10.1007/s11365-012-0246-z 